\title{
Cognitive Skills Involved in Reading Comprehension of Adolescents with Low Educational Opportunities
}

\author{
Valeria Abusamra ${ }^{1, *}$, Micaela Difalcis ${ }^{2}\left(\mathbb{D}\right.$, Gisela Martínez ${ }^{1}$, Daniel M. Low ${ }^{3}(D)$ and \\ Jesica Formoso $^{2}$ \\ 1 CIIPME-CONICET, University of Buenos Aires, Viamonte 430, Buenos Aires C1053 CABA, Argentina; \\ martinezgiselap@gmail.com \\ 2 CONICET, Institute of Psychology, University of Buenos Aires, Viamonte 430, \\ Buenos Aires C1053 CABA, Argentina; micaeladifalcis@gmail.com (M.D.); jformoso@psi.uba.ar (J.F.) \\ 3 Program in Speech and Hearing Bioscience and Technology, Harvard Medical School \& MIT, \\ Boston, MA 02115, USA; dlow@mit.edu \\ * Correspondence: vabusamra@gmail.com
}

Received: 31 July 2020; Accepted: 11 September 2020; Published: 15 September 2020

\begin{abstract}
Reading comprehension is a fundamental resource for educational and social development. It is a skill that brings into play a diverse and complex set of processes and cognitive functions based on building a mental representation of a given text. We set out to study how different domain-general and linguistic abilities explain text comprehension in a population of secondary school students with low educational opportunities. The sample consisted of 45 adolescents between the ages of 13 and 15 from two secondary schools in the Province of Buenos Aires, Argentina. Each participant was evaluated both in-group and individually for three sessions during school hours. A text comprehension screening test and a battery of tasks that measure different underlying cognitive processes were administered. Using multiple linear regression, we found that vocabulary, non-word reading, and verbal inhibition are the skills that best explain reading comprehension skills. Understanding how much different domain-general and linguistic subprocesses are associated with text comprehension is key to designing effective interventions that are also grounded in theory.
\end{abstract}

Keywords: text comprehension; vocabulary; decoding; inhibition; reading; educational opportunities; adolescents

\section{Introduction}

Reading is one of the most complex and distinctive behaviors of our species and represents, without a doubt, a key goal of education. Acquiring knowledge through reading is not only essential to successfully navigate the school system and higher education, but is also a fundamental part of everyday life and becoming a responsible and informed citizen.

This is why it is observed with concern the fact that many students fail to read and understand what they read, a difficulty that deepens if we consider cognitively more demanding tasks such as planning and producing a text (Abusamra et al. 2020). Different studies revealed that a significant proportion of adolescents and adults do not adequately understand texts, with the consequences that this generates academically and professionally (Abusamra et al. 2019; Ahmed et al. 2016; Cornoldi et al. 1996; Nation and Snowling 1997). Even basic skills such as decoding that are supposed to be acquired during primary school are found to be affected during secondary school (Lupo et al. 2019).

On top of the mounting empirical evidence, through our interventions in schools, we have found that parents, teachers, and tutors generally share the perception that students have difficulties in understanding written texts. As in any complex problem, there are multiple causes to reading 
comprehension difficulties that range from changes in schooling requirements and poor teaching conditions to the radical change in the ways children acquire literacy using technology (Abusamra 2018; Abusamra et al. 2014; Gee 2005; Kress 2003).

Two issues with reading that are especially relevant. On the one hand, reading comprehension is a cultural ability. The linguistic ability that it is based upon is a genetic property of the species. Linguistic processing, from phonology to syntax, depends on an autonomous mental module that has the property of being relatively identical for the entire species. Reading comprehension-on the contrary-is a cultural activity, as are other behaviors in which the linguistic capacity intervenes. This implies that it must be taught and exercised. Many of the reported difficulties are the result of a lack of explicit instruction, since there is not a perfect consensus on how to teach it, given it is a complex skill in which multiple factors intervene. First, if it is written text, decoding skills come into play, serving as the basis for linguistic processing in the strict sense: identifying lexemes, establishing relationships, assigning syntactic structure, constructing a mental representation that refers to a semantic space beyond the linguistic domain. In addition to linguistic processing, other functions intervene such as attention, memory, executive functions, and the ability to conceptualize and visualize (Abusamra 2010, 2018).

\subsection{The Complex Task of Building Meaning}

A crucial point during reading comprehension is establishing a kind of "transaction" between the surface information provided in the text and the reader's world knowledge. On the basis of both types of information, comprehenders construct meaning and keep a coordinated and coherent structure in their memory rather than a disjointed set of individual pieces of information (Abusamra et al. 2014; Kintsch and Rawson 2007; Snow 2002).

One of the biggest challenges in psycholinguistics is that of explaining how texts are understood. According to a multi-component perspective of reading (Abusamra et al. 2010, 2014; Cain 2009; Cain et al. 2004; De Beni 2003), there are many processes that contribute to reading comprehension: decoding (Cirino et al. 2013; Kang and Shin 2019), vocabulary (Cain 2009; Spencer et al. 2019), ranking skills, working memory (Borella et al. 2010; Cutting et al. 2009; Oakhill et al. 2005), executive functions (Arán Filippetti and López 2016; Cartoceti 2012; Demagistri et al. 2017), metacognitive abilities, the inference generation (Kendeou et al. 2008), and the processing of temporality (Abusamra 2014). Some of these processes were studied especially in relation to reading comprehension disorders.

\subsubsection{Decoding}

As stated in the Simple View of Reading model (Gough and Tunmer 1986; Hoover and Gough 1990), reading comprehension is based on the interaction of two components: decoding and oral comprehension. This not only implies that in the absence of decoding, reading comprehension is not possible, but also that a difficulty to decode will negatively affect text comprehension (Carretti et al. 2007; Perfetti et al. 2005).

Some studies have shown that in cases of reading comprehension disorders, even when decoding ability is not used as a diagnostic criterion, differences are observed between good and bad comprehenders in decoding tasks, including when these differences do not explain the nature of the deficit. These are studies that have shown that poor comprehenders read words and non-words more slowly (Perfetti and Hogaboam 1975; Perfetti et al. 1978; Ehrlich et al. 1993). There are, however, multiple studies showing that good and bad comprehenders can also not differ in any of the indices commonly used to assess decoding (e.g., reading words, non-words and texts) (Cornoldi and Oakhill 1996; Nation and Snowling 1997; Megherbi et al. 2006). They thus demonstrate the substantial independence of decoding with regards to text comprehension, which each depend on different cognitive processes and, of course, require diverse teaching resources (Pazzaglia et al. 1993; Papetti et al. 1992; Defior Citoler 2000).

One of the basic goals in the first years of primary education is for children to acquire a mastery of decoding skills, in terms of accuracy and fluency in recognizing written words as well as properly 
producing prosodic aspects of reading aloud. In the first few years of education, special emphasis is placed on the child becoming a fluent reader because automated decoding leaves cognitive resources available to deal with the high-level processes that text comprehension demands. In subsequent years, mastering reading comprehension skills becomes the main tool for successful schooling and academic training (Abusamra et al. 2019; China 2018).

The assumption that reading in high school instances is already a fully achieved skill means that, in many cases, difficulties are overlooked that become bottlenecks for students to perform text-level tasks. In national Argentine educational evaluations (ONE 2010; Aprender 2017), poor performance in text comprehension is reported but these evaluations do not report decoding skills. Fletcher et al. (2007) and Stanovich (1993) pointed out that when decoding is not performed effectively, demand is generated for cognitive resources that cannot be used to integrate information and understand texts (China 2018).

\subsubsection{The Importance of a Rich and Organized Vocabulary}

Several studies have proposed that one of the variables that is strongly associated with reading comprehension is vocabulary (Carroll 1993; Cain et al. 2003). Even though text comprehension involves integration procedures that go beyond merely lexical processing, recognizing and understanding a word's individual meaning represents an essential process.

The causal direction of this relationship is not entirely clear and although there is no broad consensus, the explanations take two forms: (1) vocabulary determines reading comprehension or vice versa or (2) there is a common variable or process that underlies the development of both abilities. Beyond this debate, there is evidence that processing at the lexical and textual levels have many elements in common. For example, it has been proposed that the "ability to infer from context" is not only the bridge between reading comprehension ability and vocabulary, but also between reading comprehension ability and verbal IQ. Trying to infer meanings that we do not know implies the start of a precise process for generating inferences that must also be activated to understand a text (Abusamra et al. 2019).

\subsubsection{Working Memory and Inhibition}

An inescapable demand when faced with a complex cognitive task is to maintain and process domain-specific information that the mind/brain is continuously receiving as a stimulus. In this way, working memory plays an essential role in human cognition and in text comprehension. In recent years, a considerable number of studies have been devoted to investigating how working memory influences the active construction of meaning while reading (Abusamra et al. 2008; Carretti et al. 2009; Daneman and Carpenter 1980; De Beni et al. 2007; Demagistri et al. 2017; Swanson and O'Connor 2009).

To build an integrated mental representation, readers must maintain the information from the text in order to establish grammatical relationships between different textual elements and integrate previous and incoming information (Ericsson and Kintsch 1995). However, mental representations are dynamic in nature: they are constructed, updated, and modified; and all these operations are carried out in working memory. Surface information (i.e., the text's explicit information) and the reader's world knowledge are activated and integrated. To avoid saturating working memory's capacity, a hierarchical process of the information is carried out that allows distinguishing what should be preserved but, fundamentally, what should be suppressed. This is why different researchers have suggested that the difficulties that arise with reading comprehension could be explained by inhibitory control deficits.

Inhibition can be defined as a mechanism of active suppression of distracting information that competes directly with information that is relevant. Inhibition is a highly flexible mechanism (Belleville et al. 2006) that allows irrelevant information to be filtered and suppressed. An inefficient inhibition mechanism inevitably affects performance during reading comprehension. This has led to the emergence in recent years of the hypothesis that misunderstanding texts could be attributed to a difficulty in inhibiting or suppressing irrelevant information (De Beni et al. 1998; Abusamra et al. 2008; 
Cartoceti et al. 2009; Pimperton and Nation 2010; Borella et al. 2010). More specifically, some studies have shown that the difficulties with inhibition among bad comprehenders could be domain-specific (Cartoceti et al. 2016; Carriquiry Colombino 2018). From this perspective, the difficulty in suppressing verbal information overloads working memory and leaves the processing system without enough resources to build meaning.

\subsection{Environmental Factors and Levels of Educational Opportunities}

Factors that have a strong influence on learning processes are the socio-economic-cultural conditions in which children are immersed and the quality of the education they receive. Different studies have revealed the effects of some of these environmental factors. Tsimpli et al. (2020) have demonstrated the effects of socioeconomic status on cognitive performance among a group of children from disadvantaged backgrounds. Piacente et al. (2006) found significant differences in performance in almost all tasks that measure emergent literacy skills with worse performance among boys from disadvantaged backgrounds. Furthermore, studies have reported the effects of socioeconomic differences on early literacy skills (Borzone 1997; Diuk et al. 2003; Diuk 2003; Piacente et al. 1990; Querejeta et al. 2005; Signorini and Piacente 2003) and on skills surrounding text comprehension (Fonseca et al. 2014; Jiménez and Cadena 2007).

Given these findings, an interesting construct to analyze is that of "educational opportunities". This construct was operationalized considering the following information: the predominant socioeconomic status of students' families; the percentage of repeaters, absenteeism, and dropouts; the equipment and resources of the educational facility equipment (library, laboratories, computer rooms, space for physical activities); the provision of a snack; and the availability of extracurricular activities (Abusamra et al. 2010, 2014).

Educational opportunities do not necessarily depend on the type of school management (public or private), but may be due to the resources available at the school, the general characteristics of its curriculum and, of course, the characteristics of the students' social-economic-cultural environment. Different studies carried out in Argentina have found a strong effect of the level of educational opportunities on performance in tasks that involve reading, writing, and reading comprehension (Abusamra et al. 2010, 2014, 2020; China 2018).

This study seeks to uncover which underlying processes (i.e., decoding, fluency, vocabulary, working memory, inhibition, flexibility) best explain reading comprehension in adolescents with low educational opportunities. We start from the following hypotheses: (a) since reading comprehension is a multicomponent ability, linguistic (vocabulary, decoding, reading efficacy) and general cognitive aspects (working memory, verbal inhibition, monitoring and flexibility) correlate with text comprehension and (b) vocabulary, decoding skills and inhibition emerge as the strongest regressors associated to text comprehension in secondary school students.

Our goals are (1) to measure the correlations between reading comprehension scores and the different cognitive and linguistic skills that are involved in this process and (2) to examine which skill-levels explain reading comprehension scores among a group of secondary school students with low educational opportunities. Knowing the effect that different cognitive operations have on reading comprehension is key to designing diagnostic instruments that are grounded in evidence-based theory.

\section{Materials and Methods}

\subsection{Participants}

The sample was made up of a total of 45 adolescents ( 23 female) ranging from 13 to 15 years old $(\mathrm{M}=14.5, \mathrm{SD}=0.87)$, who attended two public secondary schools with low educational opportunities from the Province of Buenos Aires, Argentina. Both schools receive low-income students, have approximately $30-35 \%$ of grade retention per year, present poor building infrastructure and almost no extracurricular activities. 


\subsection{Materials}

\subsubsection{Reading Comprehension (Screening)}

A narrative screening test (NST) was administered from the Test Leer para Comprender II (Abusamra et al. 2014). It is a short text followed by 10 questions with 4 response alternatives from which the participant must select the correct one (multiple choice). In all cases, there is only one correct answer and the other options have a different degree of semantic proximity in relation to the corresponding one. Although there is no time limit for its completion, the time it takes the participant to read and answer the questions is recorded.

The score (maximum $=10$ ) and the time it takes to complete the task (in minutes) are recorded.

\subsubsection{Reading Comprehension (Metacognition: Error and Inconsistency Detection)}

The Area 11 test (from now on, A11-TLC II) of the Test Leer para Comprender II program was administered (Abusamra et al. 2014). The task consists of 10 exercises that assess the ability to detect syntactic and semantic errors or inconsistencies. The task requires that the reader understand situations that can be interpreted in an alternative way, that clarify or suspend prior reading hypotheses until new information appears, and where they interpret the meaning depending on different punctuation. The score (maximum $=10$ ) and the time it takes to complete the task (in minutes) are recorded.

\subsubsection{TECLE (Reading Efficacy)}

The Collective Test of Reading Efficacy (TECLE for its acronym in Spanish), Buenos Aires version (Ferreres et al. 2011) was administered. This test, initially proposed by Marín and Carrillo (1999) and by Cuadro and Marín (2007), follows the structure of the D-OR-LEC test (Lobrot 1980). The test consists of 64 sentences in which the last word is missing. The participant's task is to complete, within a time limit of five minutes, the most amount of sentences, selecting a word among four options. One is the correct word, another is a similar but incorrect word, another is a phonologically close non-word, and finally an orthographically close non-word. The score is the result of the sum of correct answers that each participant achieves within five minutes (maximum score $=64$ ).

\subsubsection{Verbal Fluency}

Two verbal fluency tests were administered: one free (FVF) and one with semantic restriction (SVF). In the FVF task, the participant is asked to say out loud, for a minute, all the words that come to mind, except proper names and numbers. In this case, the participants are required to keep their eyes closed so that objects present in the environment do not facilitate the task. In the case of the SVF task, the participant must produce, also for one minute, as many animal names as possible.

\subsubsection{Hayling Test (Verbal Initiation and Inhibition)}

A Spanish version of the Hayling Test was administered (Cartoceti et al. 2009). The test consists of two parts that include 15 sentences each with the last word missing. Once the evaluator finishes reading a given sentence, participants must replace the missing word following the conditions of each section. In Part A, the participant must produce a word aloud that coherently completes the sentence. We record the time between when the evaluator finishes reading the incomplete sentence and when the participant says the word (in milliseconds with a stopwatch).

In Part B, the participant must produce a word aloud that is not related to the content of the sentence. That is, a word that completes the sentence incongruently with regards to the semantic-syntactic context. The time for completing the sentence is also recorded (in milliseconds). In addition, a score is assigned that takes into account the semantic closeness that the proposed word has with a correctly completed sentence: the greater the semantic closeness, the higher the score and the worse the performance. 


\subsubsection{Reading Aloud (Decoding)}

Three reading aloud tests were administered using words (RAW), non-words (RANW), and a short text (RAST). The word and non-word reading aloud tests were taken from the Batería Transpruebas (China and Ferreres 2017) and consists of two lists of 45 words and 45 non-words. Participants should read each list as quickly and accurately as possible. One point is computed for each stimulus read correctly and the total reading time is recorded (in seconds). A fragment of a short narrative text was selected to evaluate reading aloud for the RAST test (see Appendix A). Participants were asked to read the full text as quickly and accurately as possible. The total number of words read correctly, the number of errors (including additions and omissions), and the total reading time (in seconds) are recorded.

\subsubsection{Vocabulary}

The Alfa-2 Scale was administered (Feldman 2009), which has 28 sheets with 4 drawings each. After listening to a word presented by the evaluator, the participant must point to one of the 4 drawings that corresponds to the word. The number of correct answers is recorded (maximum $=28$ ).

\subsubsection{Working Memory}

Two tests were administered to assess working memory. One was an adaptation of the reduced Italian version of the Listening Span Test (Pazzaglia et al. 2000). It has 28 sentences organized in two blocks (see Appendix A). Each block contains sequences of declarative sentences that increase in length: from a minimum of two sentences to a maximum of five. The task is to judge whether the sentence's semantic content is true or false and remember, at the end of the sequences, the last word of each of the sentences. Three types of scores are reported: the total number of words remembered (LST-WR), the number of intrusions (LST-I), and the total number of correct hits regarding the truth value of the sequences (LST-TF). The second test provided is the backward digit span task of the WISC-IV (Wechsler 2005). It has 16 sequences: four 2-digit, four 3-digit, four 4-digit, and four 5-digit. Participants must listen to each sequence and then say aloud the digits that make it up backwards. The task is interrupted when the participant fails two sequences in a row. One point is added for each correct sequence.

\subsection{Procedure}

A meeting was conducted with the participating schools' administrative teams to explain the details of this research project. Then a note was sent to the student's parents or legal guardians requesting consent. It was made clear that participation was voluntary and anonymous. This research was conducted following the ethical regulation $5344 / 99$ by the National Scientific and Technical Research Council of Argentina (CONICET) and was approved and supervised by CONICET's committee. All procedures were in accordance with the 1975 Helsinki Declaration and its later amendments.

Four members of the research team administered the assessments and received appropriate training prior to the start of the study. Data collection was carried out during the second academic semester during normal class hours. The NST, A11-TLC II, and TECLE tests were administered collectively. All other tasks were administered individually.

There were three sessions in total. In the first session, the NST and TECLE were administered. This collective session lasted between 20 and $30 \mathrm{~min}$. In the second session, A11-TLC II, FVF, SVF, Hayling, and Span were administered. Finally, in the third session, the Alfa-2 Scale, the three reading aloud tasks (words, non-words, and short text) and the Listening Span Test (LST) were administered. The last two sessions lasted between 30 and 40 min per participant. Data collection took six weeks. The testing order was the same for all participants. 


\subsection{Analysis of Data}

First, we tested the normality of the different scores with a Shapiro-Wilk test with alpha $=0.05$. Then we performed a pairwise correlation between scores in order to measure the level of association between them using a Benjamini-Hochberg procedure with a false discovery rate of 0.05. Finally, to explore which independent variables significantly explain the comprehension task score, we performed multiple linear regression using a stepwise selection method using the AKAIKE information criterion (AIC) (Yamashita et al. 2007) as the criteria for selecting independent variables. For each proposed model, we report the decrease in the residual sum of squares (RSS) and AIC and the increase in $R^{2}$, the F statistic along with the associated p-values. The model is considered complete when any addition would imply a decrease in the AIC of less than 2 points.

For the regression analysis, we inspected the distribution of the standardized residuals with the Shapiro-Wilk test to assess normality, the Breusch-Pagan test for heteroscedasticity (Breusch and Pagan 1979; Cook and Weisberg 1983) and the variance inflation factor (VIF) for multicollinearity. We removed data-points with high leverage (Cook's distance $>4 / \mathrm{n}$ ) and large standardized residuals $(>3)$.

\section{Results}

First, we performed descriptive statistics and normality tests (see Table 1).

Table 1. Descriptive statistics and normality tests.

\begin{tabular}{ccccccc}
\hline Tasks & Media & SD & Min & Max & W & $p$ \\
\hline NST & 6.75 & 2.04 & 1 & 10 & 0.91 & $*$ \\
A11-TLCII & 4.29 & 2.35 & 0 & 9 & 0.96 & 0.08 \\
FVF & 25.84 & 7.85 & 8 & 39 & 0.97 & 0.35 \\
SVF & 18.47 & 5.7 & 8 & 33 & 0.98 & 0.63 \\
Hayling A & 963 & 613 & 344 & 3660 & 0.76 & $*$ \\
Hayling B & 0.76 & 0.53 & 0 & 1.93 & 0.95 & 0.04 \\
Hayling B (time) & 2413 & 1629 & 447 & 8438 & 0.84 & 0 \\
RANW & 36.86 & 3.66 & 29 & 45 & 0.98 & 0.44 \\
RANW (time) & 66.82 & 18.89 & 37 & 117 & 0.93 & $*$ \\
RAW & 44.24 & 1.05 & 41 & 45 & 0.72 & $*$ \\
RAW (time) & 36.73 & 8.5 & 25 & 60 & 0.87 & $*$ \\
LST-I & 2.26 & 2.21 & 0 & 13 & 0.75 & $*$ \\
LST-WR & 18.28 & 3.74 & 8 & 25 & 0.96 & 0.17 \\
LST-TF & 26.46 & 2.04 & 17 & 28 & 0.73 & $*$ \\
Alfa-2 Scale & 3.2 & 3.19 & 0 & 13 & 0.87 & $*$ \\
RAST & 134 & 26.03 & 93 & 212 & 0.94 & 0.01 \\
RAST (time) & 23.81 & 3.21 & 14 & 28 & 0.9 & $*$ \\
Span & 4.1 & 1.14 & 2 & 8 & 0.88 & $*$ \\
TECLE & 43.75 & 11.01 & 22 & 64 & 0.98 & 0.43 \\
\hline$* p$-value $<0.05$. W $=$ Shapiro-Wilk statistic; $p=p$-value. &
\end{tabular}

As seen in Table 1, given that most task-specific distributions are significantly different from a normal distribution, we carried out the correlation analysis using Spearman's rank correlation (Table 2). 
Table 2. Pairwise correlations (rho) across all variables.

\begin{tabular}{|c|c|c|c|c|c|c|c|c|c|c|c|c|c|c|c|c|c|c|}
\hline & 2. & 3. & 4. & 5. & 6. & 7. & 8. & 9. & 10. & 11. & 12. & 13. & 14. & 15. & 16. & 17. & 18. & 19. \\
\hline 1. NST & 0.39 * & -0.16 & $-0.32 *$ & -0.27 & $0.37 *$ & 0.18 & 0.19 & $0.34 *$ & 0.18 & -0.04 & $0.46^{*}$ & -0.27 & $0.30 *$ & $0.45 *$ & -0.22 & $-0.34 *$ & $-0.33 *$ & $0.41 *$ \\
\hline 2. A11-TLCII & - & -0.18 & $-0.40 *$ & $-0.41 *$ & $0.50 *$ & $0.47 *$ & $0.35 *$ & $0.45 *$ & 0.12 & -0.12 & $0.36 *$ & -0.17 & $0.33 *$ & $0.39 *$ & -0.15 & $-0.37 *$ & $-0.41 *$ & 0.52 * \\
\hline 3. Hayling A & & - & $0.49 *$ & 0.08 & 0.03 & -0.03 & -0.27 & -0.17 & 0.16 & 0.15 & 0.10 & 0.09 & $-0.51 *$ & -0.13 & 0.54 * & 0.15 & -0.15 & -0.16 \\
\hline 4. Hayling B (time) & & & - & 0.40 * & $-0.32 *$ & $-0.38 *$ & -0.17 & $-0.34 *$ & -0.12 & 0.21 & -0.12 & 0.23 & -0.16 & -0.09 & 0.25 & 0.24 & -0.02 & -0.20 \\
\hline 5. Hayling B & & & & - & -0.38 * & -0.39 * & 0.02 & $-0.38 *$ & -0.13 & 0.23 & $-0.39 *$ & $0.33 *$ & $-0.37^{*}$ & -0.22 & 0.13 & 0.30 * & 0.21 & -0.08 \\
\hline 6. TECLE & & & & & 0.00 & 0.36 * & 0.11 & 0.19 & 0.37 * & -0.26 & $0.48^{*}$ & $-0.38 *$ & -0.01 & 0.27 & -0.16 & -0.51 * & -0.54 * & 0.18 \\
\hline 7. FVF & & & & & & 0 & $0.55 *$ & $0.40 *$ & -0.02 & -0.11 & 0.18 & -0.27 & 0.26 & 0.20 & 0.13 & -0.20 & -0.13 & 0.16 \\
\hline 8. SVF & & & & & & & - & 0.19 & -0.01 & -0.23 & 0.07 & -0.20 & $0.33 *$ & $0.36^{*}$ & 0.05 & -0.19 & -0.13 & 0.38 * \\
\hline 9. Span & & & & & & & & - & -0.12 & 0.25 & $0.33 *$ & -0.34 * & 0.07 & 0.09 & -0.06 & $-0.32 *$ & 0.12 & 0.06 \\
\hline 10. RAW & & & & & & & & & - & -0.24 & $0.39 *$ & -0.26 & -0.06 & 0.21 & 0.05 & $-0.41 *$ & -0.49 * & 0.28 \\
\hline 11. RAW (time) & & & & & & & & & & - & $-0.29 *$ & $0.76^{*}$ & 0.12 & -0.21 & -0.22 & $0.67^{*}$ & 0.20 & -0.05 \\
\hline 12. RANW & & & & & & & & & & & - & -0.50 * & 0.09 & 0.40 * & -0.09 & -0.51 * & $-0.47 *$ & 0.19 \\
\hline 13. RANW (time) & & & & & & & & & & & & & 0.10 & -0.28 & -0.19 & $0.78^{*}$ & $0.40 *$ & -0.02 \\
\hline 14. LST-WR & & & & & & & & & & & & & - & 0.27 & $-0.52 *$ & -0.04 & -0.07 & 0.26 \\
\hline 15. LST-TF & & & & & & & & & & & & & & - & -0.08 & -0.43 * & -0.43 * & 0.53 * \\
\hline 16. LST-I & & & & & & & & & & & & & & & - & -0.02 & 0.06 & -0.16 \\
\hline 17. RAST (time) & & & & & & & & & & & & & & & & - & $0.56^{*}$ & $-0.34 *$ \\
\hline 18. RAST & & & & & & & & & & & & & & & & & - & $-0.36^{*}$ \\
\hline 19. Alfa-2 Scale & & & & & & & & & & & & & & & & & & - \\
\hline
\end{tabular}

* significant $p$-value after Benjamini-Hochberg multiple comparison correction. 
As seen in Table 2, the variables that show a significant positive correlation with the reading comprehension NST test after multiple comparison corrections are A11-TLCII (error and inconsistency detection), TECLE (reading efficacy), Span, RANW (reading aloud-non-words), LST-WR, LST-TF, and Alfa-2 Scale. The variables that show a significant negative correlation with the NST test are the Hayling test B (time), RAST (time), and RAST (number of errors).

Next, multiple regression was applied with the NST test score as the dependent variable. The independent variables were selected from those that were significantly associated with the dependent variable and were added to the model with the stepwise selection method. The results can be found in Table 3.

Table 3. Stepwise regression.

\begin{tabular}{cccccc}
\hline Model & RSS & AIC & F & $p$ & $\boldsymbol{R}^{\mathbf{2}}$ \\
\hline Intercept & - & 69.57 & - & - & - \\
+ RANW & 157.20 & 60.29 & 12.26 & $*$ & 0.22 \\
+ Alfa-2 Scale & 133.53 & 55.95 & 10.77 & $*$ & 0.34 \\
+ Hayling B (time) & 122.58 & 53.10 & 8.54 & $*$ & 0.39 \\
+ LST-TF & 118.05 & 53.40 & 7.11 & $*$ & 0.42
\end{tabular}

${ }^{*} p$-value $<0.05$. RSS: residual sum of squares; AIC: AKAIKE information criteria, $p: p$-value; $R^{2}$ : coefficient of determination.

The first model includes the independent variable RANW as an independent variable. It is significant $\left(\mathrm{F}_{1,43}=12.26, p<0.001\right)$ and explains $22 \%$ of the variance of NST $\left(R^{2}=0.22\right)$. This model implies a significant improvement compared to that with the intercept only since the AIC is reduced by nine points (from 69.57 to 60.29). Further independent variables (Alfa-2 Scale and Hayling B (time)) are included accounting for $39 \%$ of the variance of the NST until the fourth model adds to the LST-TF variable which only increases the AIC by 0.3 points; since a decrease of at least two points in the AIC was previously established as a cut-off criterion, this variable is not included. The analysis of the standardized residuals showed two data-points with large residuals $(>3)$ and high leverage (Cook's D of 0.30 and 0.25 ) and these were therefore removed and the regression analysis was repeated. Residuals do not depart significantly from normality (Shapiro-Wilk $=0.96, p=0.15$ ) or a homoscedastic distribution (Breusch-Pagan $(3)=3.78, p=0.29$ ). Additionally, no multicollinearity was detected.

The final model includes the NST variable as dependent and the RANW, Alfa-2 Scale and Hayling test $\mathrm{B}$ (time) independent variables $\left(\mathrm{F}_{3,39}=15.02, p<0.001\right)$ and explains $54 \%$ of the variance of the response variable. Both RANW $(\beta=0.26, p<0.001)$ and Alfa-2 Scale $(\beta=0.24, p<0.01)$ have a significant positive effect on the dependent variable. As values on these tasks increase, the average scores on the NST task increase. Hayling test B (time), on the other hand, shows a significant negative effect $(\beta=-0.0006, p<0.01)$ on the response variable. As the time to complete the inhibitory control task increases, the mean NST scores decrease.

\section{Discussion}

The goal of this study was to determine the cognitive and linguistic processes that best explain reading comprehension by a group of secondary school students with low educational opportunities. The results of our study indicate that decoding of non-words (although not decoding of words), vocabulary (Alfa-2 Scale), and verbal inhibition explain a substantial amount of the variance $(54 \%)$ in reading comprehension.

One of the main goals of teaching at the beginning of primary education is that children learn to recognize written words accurately and with enough automation to go from "learning to read" to "reading to learn". Once this process is automated, mastering reading comprehension skills becomes the main tool for academic training and the basis for increasing world knowledge. However, many students reach the stage where they are supposed to "read to learn" with less ability but with increasing demand across almost all subjects. Added to this problem is the mistaken belief that it is 
no longer necessary to teach to comprehend, and a learning bottleneck appears which often drags along into higher education. Considering these issues and the fact that reading comprehension is a skill that depends heavily on explicit teaching, it is essential to know the processes involved in textual level processing to understand how difficulties manifest, to develop methods that can identify these difficulties, and to plan programs to improve these skills.

The present study's results are convergent with previous work that has investigated the effect of different cognitive factors in reading comprehension (Catts et al. 2005; Cromley and Azevedo 2007; Verhoeven and Leeuwe 2008; Tilstra et al. 2009; Cromley et al. 2010; Ahmed et al. 2016; Duncan et al. 2016). The direct and inferential mediation model (DIME) (Cromley and Azevedo 2007) was used to examine how vocabulary, decoding skills, world knowledge, inference generation, and reading strategies influence text comprehension among secondary school students. From the study of a group of students between 14 and 15 years old, the authors identified that vocabulary and general world knowledge were strongly associated with text comprehension. Furthermore, they reported that inferential capacity and decoding in terms of recognition and fluency also had effects, although weaker. Vocabulary and prior knowledge exerted additional indirect effects mediated by inference-making ability.

The work of Ahmed et al. (2016) focused on the correlation between different variables and reading comprehension of middle and high school students, noting that vocabulary knowledge explained reading comprehension ability across all school years. They observed that vocabulary knowledge correlated with general world knowledge; this seems to indicate that students with richer vocabularies also have a greater background with which to understand texts.

In the case of Duncan et al. (2016), the aim was to analyze the variables that explain reading comprehension in adolescents using fiction and non-fiction texts. Word recognition, along with reading fluency, explained $53 \%$ of the variance in text comprehension tasks. Different genres may entail different cognitive demands and superstructural characteristics. Some studies have shown that in the case of narrative texts, word recognition skills have an important effect, while expository texts seem to require higher levels of world knowledge (Best et al. 2008; Eason et al. 2012; García and Cain 2014).

While previous work has investigated reading comprehension abilities in adolescents, the specific contribution of this current study is to further understand reading comprehension abilities in disadvantaged students and how it is associated with other linguistic and extra-linguistic skills. As we have pointed out, the socio-economic-cultural conditions in which each child is immersed strongly influences the results of any learning process. Evidence from different sources supports this statement. Multiple studies have shown that differences in educational opportunities explain the breadth of children's vocabulary in preschool, resulting in differences of up to several thousand words between students with low and high educational opportunities (Biemiller 2006). It has been reported that beyond individual cognitive differences, contextual opportunities have a decisive influence (Biemiller 2003). When these differences are not addressed early on, they are exacerbated through a negative cycle: students with reduced vocabularies tend to read less, understand less, and in turn learn fewer words (Diuk et al. 2010; Joshi 2005; Rosemberg and Stein 2016; Rosemberg et al. 2011). If this impact can already be observed as literacy and reading acquisition develop, a similar or even more pronounced effect should be expected in more complex skills such as reading comprehension, which involves higher-order cognitive processes. There are few studies in Spanish that have addressed the effect of socio-economic conditions on reading comprehension. Jiménez and Cadena (2007) studied students (grade 3-6) from two countries, Guatemala and Spain, and found some differences in the prevalence of specific learning disabilities in reading between both countries but no significant differences in cognitive processes that are involved in reading and spelling acquisition. While they compared samples between a developing country and a developed country, they did not determine the socio-economic status of their samples. (Ferreres et al. 2010), when controlling for educational opportunities, found a strong effect of educational opportunities on reading comprehension while creating norms for the Test Leer para comprender (Abusamra et al. 2010, 2014) but did not measure other cognitive abilities beyond reading comprehension. Therefore, our study expands upon previous 
research in that it finds that in Latin American adolescents with low educational opportunities reading comprehension is significantly associated with multiple cognitive abilities including decoding, vocabulary, and verbal inhibition.

Studying the effect that educational opportunities have on reading comprehension in high school students is extremely important. The acquisition of reading and comprehension skills is a crucial resource for students and citizens and differences in their development create a gap between those who read and understand and those who do not. What is more pressing is that in Latin America, the prevalence of reading difficulties in children from disadvantaged contexts is much higher than that reported worldwide: $25 \%$ in Latin America and between 5\% and 15\% worldwide (Capovilla and Capovilla 2004). Therefore, it is paramount and urgent to further understand the nature of reading comprehension difficulties that Latin American adolescents from low educational opportunities face.

\subsection{The Effect of an Ability That Does Not Disappear: Decoding}

Although there are studies that have shown that decoding contributes consistently in the early stages of schooling and that it seems to decrease in early adolescence, it has also been shown that its effect does not disappear (García and Cain 2014). In our study we evaluated different aspects related to reading, through three tests: one for reading words and non-words, that more specifically rely on decoding, the TECLE aimed at evaluating reading efficacy (precision and speed) and a reading-aloud task to examine fluency in reading. Although these last two correlate with the reading comprehension task, the precision in the non-word reading task (decoding) turns out to be more important in the multivariable regression analysis when combined with other independent variables.

The inclusion of tests that measure decoding under different conditions has to do with the impact these conditions could have on reading: it has been shown that reading words in context can improve the precision and efficacy with which you read (Kim et al. 2011; Kim et al. 2012).

In the case of the present study, the reading of non-words together with the vocabulary task and the verbal inhibition task explain an important percentage of the variance. The results of previous investigations are mixed. In one of the few studies carried out on a group of readers without difficulties, Catts et al. (2005) found that the word identification task uniquely explained the variance in the reading comprehension among 14 to 15 years old adolescents. Other works such as Vellutino et al. (2007) could not establish this association, although they did find a significant positive correlation between oral comprehension and text comprehension. Overall, different profiles have been reported: poor comprehension with weak abilities at the oral language level in the absence of word decoding problems (Cutting et al. 2009; Sesma et al. 2009), as well as the opposite, good oral comprehension with difficulties in decoding (Brasseur-Hock et al. 2011). Following the Simple View of Reading, we could interpret our results by stating that word identification skills may be necessary for reading comprehension in adolescents. Another possible explanation can be put forward by following the lexical quality hypothesis that decoding and vocabulary are critical determinants of reading comprehension (Verhoeven and Leeuwe 2008).

\subsection{Vocabulary as an Essential Variable}

The results are quite heterogeneous regarding the relationship between certain variables and text comprehension in secondary school. However, beyond the discrepancies, almost all studies coincide in recognizing an essential contribution of vocabulary in all instances of schooling. Verhoeven and Leeuwe (2008) demonstrated from a structural model that decoding words, vocabulary and listening comprehension had a significant impact in the first grades of elementary school. Florit et al. (2014) proved that lexical knowledge, both receptive and expressive, explains a large proportion of the variance of kindergarten children's listening comprehension ability. It has even been shown that vocabulary constitutes an essential variable for word recognition (Chiappe et al. 2004; Levelt et al. 1999). The results of these studies revealed that children that possess a mental lexicon with a greater number 
of lexical entries and hence greater phonological and semantic knowledge have a clear advantage over those with poorer lexicons since they achieve more efficient and accurate word identification.

At this point, it is important to distinguish what Ouellette (2006) called vocabulary depth and breadth. This distinction is derived from mental lexicon models. According to the classic models of lexicon access (Forster 1976; Fromkin 1992), the lexicon is a long-term memory in which phonological, orthographic, and semantic representations of words are stored. In this sense it is important to distinguish between the number of phonological/orthographic lexicon entries (vocabulary breadth) from the stored semantic content (vocabulary knowledge depth). The lexicon is culturally influenced and is built up progressively. From a very early age, a child can store the phonological form of a word without having any information about its meaning or can even associate it with an incorrect meaning that must be adjusted later on. This distinction may help better understand the relationship between vocabulary and reading comprehension. In Ouellette (2006) work, the breadth of receptive vocabulary (measured with a task similar to the Alfa-2 scale) only explained decoding performance. Meanwhile, expressive vocabulary breadth (measured by a verb and noun naming task) explained visual word recognition. Finally, vocabulary depth knowledge (definitions or synonyms) was associated with reading comprehension beyond vocabulary breadth measures.

Different from what Ouellette (2006) found, the results of the present study show that the breadth of receptive vocabulary can also explain performance in a reading comprehension task. This difference could be linked to the types of demands that the text comprehension task of each study used or to the use of a population of students with low educational opportunities in our study. In future studies, we will be including students with high educational opportunities.

What is the causal direction between vocabulary and reading comprehension? It is not clear whether there is a specific direction, but there is evidence that there could be mechanisms in common between these two abilities. Cain et al. (2004) have proposed that the ability to infer meaning from context may be the common factor.

\subsection{The Importance of Verbal Inhibition}

Understanding a text implies building a model of the situation that is consistent with the explicit content (Graesser et al. 1997; Johnson-Laird 1983; Van Dijk and Kintsch 1983; Zwaan et al. 1995a). There is evidence that readers encode five conceptual dimensions or indexes of a current situation: time, space, causality, intent, and protagonists. To integrate the information from these five dimensions, readers gradually update their mental representations and build a situation model or an interconnected network of situation models. There are three important concepts related to the development of situation models: building, updating, and changing (Zwaan et al. 1995a; Zwaan et al. 1995b; Zwaan and Radvansky 1998; Zwaan et al. 1998). The model is built as a result of transactions between the surface information and the reader's world knowledge. However, as reading progresses, it is necessary to integrate already processed information with new relevant information. In this way, if the incoming information is integrated into the active mental model, the representation is updated, but if a breakdown of some of the model's dimensions (e.g., time, space, protagonists) occurs, the reader must close the ongoing situation model and start a new one.

The concept of inhibition plays a central role in the processes that underlie reading comprehension and situation model building. A good comprehender must highlight key information as well as inhibit irrelevant stimuli or representations, and these processes seem to be equally important (Canet Juric and Burín 2016). In recent years, the hypothesis arose that the performance of poor comprehenders could be attributed to a difficulty in inhibiting irrelevant information (De Beni et al. 1998; Abusamra et al. 2008; Cartoceti et al. 2009; Pimperton and Nation 2010; Borella et al. 2010).

Our results are convergent with previous studies that highlight inhibition-in particular, verbal inhibition—as a key mechanism of reading comprehension (Abusamra et al. 2008; Cartoceti 2012). In the present study, the time it takes participants to complete the second part of the Hayling test is significantly negatively associated with reading comprehension: the shorter the time it takes to 
inhibit a more natural response, the better the reading comprehension. Updating and inhibiting operate together, like two sides of the same coin. Bad comprehenders often fail at both. Difficulty in suppressing verbal information overloads working memory and leaves the processing system with no resources available to process relevant information.

\subsection{Limitations and Future Direction}

This study presents some limitations that can be overcome in future work. First, a larger sample size could have led to some other additional variables emerging as important regressors. There are variables that were marginally significant and were not included in the regression model.

Furthermore, only one measure of inhibition was used, which is one of the variables that explains the variance of the comprehension task. Including more measures of this ability could reinforce its importance.

Furthermore, a pending goal is to examine whether the variables that explain reading comprehension generalize when applying this battery to a group of students from different educational opportunities. Understanding which specific skills are involved in different populations could help bring evidence to debates around how to improve educational policies and could help reevaluate the role of the current educational system in promoting equal opportunities.

Author Contributions: V.A.: conceptualization, data collection and writing; M.D. and G.M.: data collection and writing; J.F.: analysis and writing; D.M.L.: analysis and writing. All authors have read and agreed to the published version of the manuscript.

Funding: This research was founded by grant 22920180100027CO (Proyecto de investigación de UE, CONICET, Argentina). D.M.L. was supported by the US National Institutes of Health NIDCD T32 (5T32DC000038-28).

Conflicts of Interest: The authors declare no conflict of interest.

\section{Appendix A}

Reading aloud: short test (RAST)

“Teníamos un juguete” by Hernán Casciari (adapted version)

Teníamos un juguete; era el más divertido del mundo. No lo habíamos inventado nosotros pero jugábamos mejor que sus inventores. Empezamos a jugar en la vereda, en los patios, en invierno y verano, hasta que un día algunos de nosotros, los que jugaban mejor, dejaron sus empleos y se dedicaron por completo. ¡Y qué bien jugaban!

Era tan grande la belleza de sus movimientos que muchos dejamos de jugar y nos pusimos a mirarlos. Armamos clubes sociales, construimos tribunas de madera y de cemento, solamente para ver de cerca a los mejores de cada barrio. Después organizamos torneos semanales, discutimos reglas y elegimos colores para las camisetas. Éramos hombres, pero actuábamos como chicos la mañana del seis de enero.

¡Qué bien nos salía cantar! Pronto averiguamos que no solo éramos buenos con el juguete, sino también mirando el juego. No habíamos resultado espectadores tristes, como en otros continentes. Nosotros nos involucrábamos, tirábamos kilos de papel picado para recibir a los nuestros y componíamos canciones de aliento.

Un día se hicieron tan numerosas las hinchadas, y tan efusivas, que tuvimos que poner barras de fierro en las tribunas, a la altura de la cadera, para no caernos en avalancha por culpa de la emoción. Más tarde esa barra de metal sirvió para que el hincha con mejor garganta, subido a ella, dirigiera el coro improvisado. Bautizamos a este hincha con el nombre de «barrabrava», porque sus malabares eran de vértigo.

En esa época empezamos a exagerar la emoción que sentíamos. Los hinchas, que hasta entonces caricaturizábamos pequeñas guerras ficticias, olvidamos que actuábamos en chiste. Empezamos a llamarle «pasión» a nuestra simpatía por un club. 
Listening Span Test (adapted version)

Block 1

El último mes del año se llama diciembre (true)

Se sabe que hay vida humana en otros planetas (false)

La vaca es un mamífero con cuatro patas y una cola (true)

En un taxi pueden viajar al mismo tiempo veinte personas (false)

Cada vez que pasa un tren, se baja la barrera (true)

Una semana está compuesta por treinta y dos días (false)

El agua de mar es particularmente rica en sal (true)

La gallina es un animal que pone huevos (false)

Los anteojos sirven para escuchar mejor el sonido (true)

Un desierto es una inmensa masa de agua sin peces (false)

El perro es un animal doméstico como el gato (true)

Los seres humanos pueden vivir varios días sin oxígeno (false)

Cuando hace mucho frío usamos gorros de lana y guantes (true)

La estación más calurosa del año es el verano (true)

Block 2

La bicicleta es un medio de transporte que tiene dos ruedas (true)

África es un continente frío que se encuentra cerca del polo (false)

La zeta es la primera letra de nuestro abecedario (false)

En cada una de las manos, tenemos cinco dedos (true)

La caña de pescar se usa para cazar moscas (false)

Si te portas mal, tu mamá te da un premio (false)

Los leones y los elefantes pueden verse en un circo (true)

El fútbol es un deporte que se practica en el mar (false)

Una isla es una porción de tierra rodeada de agua (true)

Las focas son animales que viven en el desierto (false)

El canario es un animal que tiene cuatro patas (false)

Las clases empiezan en marzo y terminan en diciembre (true)

El diariero es un señor que trabaja vendiendo pan (false)

Te podés morir si te pica una víbora (true)

\section{References}

Ahmed, Yusra, David J. Francis, Mary York, Jack M. Fletcher, Marcia Barnes, and Paulina Kulesz. 2016. Validation of the direct and inferential mediation (DIME) model of reading comprehension in grades 7 through 12 . Contemporary Educational Psychology 44: 68-82. [CrossRef]

Aprender. 2017. Aprender 2016. Análisis de desempeños por capacidades y contenidos. Nivel primario; Secretaría de Evaluación Educativa. Ministerio de Educación y Deportes. Presidencia de la Nación. Available online: www.bnm.me.gov.ar/giga1/documentos/EL005596.pdf (accessed on 20 July 2020).

Arán Filippetti, Vanessa, and Mariana Beatriz López. 2016. Predictores de la comprensión lectora en niños y adolescentes: El papel de la edad, el sexo y las funciones ejecutivas. Cuadernos de Neuropsicología/Panamerican Journal of Neuropsychology 10: 23-44. 
Abusamra, Valeria. 2010. Comprensión de textos: El papel de la Información Sintáctico-Semántica en la Cosntrucción y Disponibilidad de Representaciones Mentales. Un Studio Experimental. Ph.D. thesis, Universidad de Buenos Aires, Buenos Aires, Argentina. Available online: http://repositorio.filo.uba.ar/ handle/filodigital/1602 (accessed on 30 December 2010).

Abusamra, Valeria. 2014. Temporal connections: Before and after in reading comprehension. Estudios en Psicología/Studies in Psychology 35: 636-47. [CrossRef]

Abusamra, Valeria. 2018. Lectores del siglo XXI: Cuadernos de Apoyo Didáctico. Buenos Aires: Santillana.

Abusamra, Valeria, Romina Cartoceti, Alejandro Raiter, and Aldo Ferreres. 2008. Una perspectiva cognitiva en el estudio de la comprensión de textos. Psico Porto Alegre, PUCRS 39: 352-61.

Abusamra, Valeria, Aldo Ferreres, Alejandro Raiter, Rossana De Beni, and Cesare Cornoldi. 2010. Test Leer para Comprender (TLC). Buenos Aires: Paidós.

Abusamra, Valeria, Romina Cartoceti, Aldo Ferreres, Alejandro Raiter, Rossana De Beni, and Cesare Cornoldi. 2014. Test Leer para Comprender II (TLC-II). Buenos Aires: Paidós.

Abusamra, Valeria, Nancy China, and Aldo Ferreres. 2019. Chapter 4: De aprender a leer a leer para aprender. Un abordaje cognitivo de la lectura y la comprensión de textos. In Neuroeducación y Diversidad. Herramientas para Potenciar las diferentes Maneras de Aprender. Edited by Liliana Bakker and Josefina Rubiales. Buenos Aires: Akadia, pp. 978-87.

Abusamra, Valeria, Agustina Miranda, Romina Cartoceti, Micaela Difalcis, Anna Re, and Cesare Cornoldi. 2020. BEEsc Batería para la Evaluación de la Escritura. Buenos Aires: Editorial Paidós.

Belleville, Sylvie, Nancie Rouleau, and Martial Van der Linden. 2006. Use of the Hayling Task to Measure Inhibition of Prepotent Responses in Normal Aging and Alzheimer's Disease. Brain and Cognition 62: 113-19. [CrossRef]

Best, Rachel M., Randy G. Floyd, and Danielle S. Mcnamara. 2008. Differential Competencies Contributing to Children's Comprehension of Narrative and Expository Texts. Reading Psychology 29: 137-64. [CrossRef]

Biemiller, Andrew. 2003. Using stories to promote vocabulary. In Ponencia Presentada en el Simposio "Fostering Early Narrative Competency: Innovations in Instruction". Orlando: International Reading Association.

Biemiller, Andrew. 2006. Vocabulary Development and Instruction: A Prerequisite for Schooling Learning. In Handbook of Early Literacy Research. Edited by En D. K. Dickinson and Susan. B. Neuman. New York: The Guilford Press, vol. 2, pp. 41-51.

Borella, Erika, Barbara Carretti, and Santiago Pelegrina. 2010. The Specific Role of Inhibition in Reading Comprehension in Good and Poor Comprehenders. Journal of Learning Disabilities 43: 541-52. [CrossRef]

Borzone, Ana María. 1997. El Proceso de Alfabetización en Niños Pequeños: Diferencias Socioculturales. Ph.D. thesis, Universidad de Buenos Aires, Buenos Aires, Argentina. Unpublished.

Brasseur-Hock, Irma F., Michael F. Hock, Michael J. Kieffer, Gina Biancarosa, and Donald D. Deshler. 2011. Adolescent Struggling Readers in Urban Schools: Results of a Latent Class Analysis. Learning and Individual Differences 21: 438-52. [CrossRef]

Breusch, Trevor S., and Adrian R. Pagan. 1979. A simple test for heteroscedasticity and random coefficient variation. Econometrica: Journal of the Econometric Society, 1287-94. [CrossRef]

Cain, Kate. 2009. Making Sense of Text: Skills That Support Text Comprehension and Its Development. Perspectives on Language and Literacy 35: 11-14.

Cain, Kate, Jane Oakhill, and Carsten Elbro. 2003. The Ability to Learn New Word Meanings from Context by School-Age Children with and without Language Comprehension Difficulties. Journal of Child Language 30: 681-94. [CrossRef] [PubMed]

Cain, Kate, Jane Oakhill, and Kate Lemmon. 2004. Individual Differences in the Inference of Word Meanings from Context: The Influence of Reading Comprehension, Vocabulary Knowledge, and Memory Capacity. Journal of Educational Psychology 96: 671-81. [CrossRef]

Canet Juric, Lorena, and Débora Burín. 2016. Chapter II: La Memoria de Trabajo: Escritorio, Pizarra, Energía Mental. In ¿Quién dirige la batuta? Funciones Ejecutivas: Herramientas para la regulación de la mente, la emoción y la acción. Edited by Isabel Introzzi and Lorena Canet Juric. Mar del Plata: EUDEM, pp. 14-39.

Capovilla, Alessandra Gotuzo Seabra, and Fernando César Capovilla. 2004. Alfabetização: Método Fônico, 3rd ed. São Paulo: Memnon.

Carretti, Bárbara, Rossana De Beni, and Cesare Cornoldi. 2007. Disturbi della comprensione del testo. In Difficoltà e Disturbi dell'Apprendimento. Edited by Cesare Cornoldi. Bologna: Il Mulino, pp. 143-62. 
Carretti, Barbara, Erika Borella, Cesare Cornoldi, and Rossana De Beni. 2009. Role of Working Memory in Explaining the Performance of Individuals with Specific Reading Comprehension Difficulties: A Meta-Analysis. Learning and Individual Differences 19: 246-51. [CrossRef]

Carriquiry Colombino, Carolina. 2018. Comprensión Lectora y Funciones Ejecutivas: Contribución de Habilidades Ejecutivas a la Comprensión Lectora en Niños con y sin Dificultades. Magister thesis, Instituto Universitario Hospital Italiano, Buenos Aires, Argentina. Available online: http://trovare.hospitalitaliano.org.ar/greenstone/ collect/areas/index/assoc/D1005.dir/tesis-carriquiry.pdf (accessed on 15 June 2020).

Carroll, John Bissell. 1993. Human Cognitive Abilities: A Survey of Factor-Analytic Studies. New York: Cambridge University Press.

Cartoceti, Romina V. 2012. Inhibitory Control and Reading Comprehension: Evidences from Specific Verbal Domain. Neuropsicología Latinoamericana 4: 65-85.

Cartoceti, Romina, Sampedro Bárbara, Abusamra Valeria, and Aldo Ferreres. 2009. Evaluacion de la iniciación y supresión de respuesta verbal en niños. Revista Fonoaudiologica 52: 9-24.

Cartoceti, Romina, Valeria Abusamra, Rossana De Beni, and Cesare Cornoldi. 2016. Comprensión de Textos En Contextos Desfavorecidos: El Efecto de Un Programa de Intervención En La Habilidad Para Detectar Errores e Incongruencias En Textos Escritos. Interdisciplinaria 33: 111-28. [CrossRef]

Catts, Hugh W., Tiffany P. Hogan, and Suzanne M. Adlof. 2005. Developmental Changes in Reading and Reading Disabilities. In The Connections between Language and Reading Disabilities. Edited by Hugh W. Catts and Alan G. Kamhi. Mahwah: Lawrence Erlbaum Associates, pp. 25-40.

Chiappe, Penny, Dan L. Chiappe, and Alexandra Gottardo. 2004. Vocabulary, Context, and Speech Perception among Good and Poor Readers. Educational Psychology 24: 825-43. [CrossRef]

China, Nancy. 2018. Validez, Confiabilidad y Datos Normativos de Un Test Breve Para La Medición de La Eficacia Lectora En Alumnos de Escuela Primaria. Ph.D. thesis, Universidad Nacional de La Plata, Buenos Aires, Argentina. Available online: http://sedici.unlp.edu.ar/handle/10915/68404 (accessed on 15 June 2020).

China, Nancy, and Aldo Ferreres. 2017. Evaluación de los procesos lexicales y sublexicales involucrados en la recuperación de la forma fonológica y ortográfica de las palabras: La Batería "transpruebas". Revista Argentina de Neuropsicología 32: 1-17.

Cirino, Paul T., Melissa A. Romain, Amy E. Barth, Tammy D. Tolar, Jack M. Fletcher, and Sharon Vaughn. 2013. Reading Skill Components and Impairments in Middle School Struggling Readers. Reading and Writing 26: 1059-86. [CrossRef]

Cook, R. Dennis, and Sanford Weisberg. 1983. Diagnostics for heteroscedasticity in regression. Biometrika 70: 1-10. [CrossRef]

Cornoldi, Cesare, and Jane Oakhill. 1996. Reading Comprehension Difficulties: Processes and Intervention. Hillsdale: Erlbaum.

Cornoldi, Cesare, Rossana De Beni, and Francesca Pazzaglia. 1996. Profiles of Reading Comprehension Difficulties: An Analysis of Single Cases. In Reading Comprehension Difficulties: Processes and Interventions. Edited by Cesare Cornoldi and Jane Oakhill. Mahwah: Erlbaum, pp. 113-36.

Cromley, Jennifer G., and Roger Azevedo. 2007. Testing and Refining the Direct and Inferential Mediation Model of Reading Comprehension. Journal of Educational Psychology 99: 311-25. [CrossRef]

Cromley, Jennifer G., Lindsey E. Snyder-Hogan, and Ulana A. Luciw-Dubas. 2010. Reading Comprehension of Scientific Text: A Domain-Specific Test of the Direct and Inferential Mediation Model of Reading Comprehension. Journal of Educational Psychology 102: 687-700. [CrossRef]

Cuadro, Ariel, and Javier Marín. 2007. Subtipos de lectores retrasados en español. Ciencias Psicológicas 1: $133-48$.

Cutting, Laurie E., April Materek, Carolyn AS Cole, Terry M. Levine, and E. Mark Mahone. 2009. Effects of Fluency, Oral Language, and Executive Function on Reading Comprehension Performance. Annals of Dyslexia 59: 34-54. [CrossRef]

Daneman, Meredyth, and Patricia A. Carpenter. 1980. Individual Differences in Working Memory and Reading. Journal of Memory and Language 19: 450-66. [CrossRef]

De Beni, Rossana. 2003. Nuova Guida Alla Comprensione Del Testo. Trento: Edizioni Erickson, vol. 4.

De Beni, Rossana, Paola Palladino, Francesca Pazzaglia, and Cesare Cornoldi. 1998. Increases in Intrusion Errors and Working Memory Deficit of Poor Comprehenders. The Quarterly Journal of Experimental Psychology Section A 51: 305-20. [CrossRef] [PubMed] 
De Beni, Rossana, Erika Borella, and Barbara Carretti. 2007. Reading Comprehension in Aging: The Role of Working Memory and Metacomprehension. Aging, Neuropsychology, and Cognition 14: 189-212. [CrossRef] [PubMed]

Defior Citoler, Sylvia. 2000. Las Dificultades de Aprendizaje: Enfoque Cognitivo. Málaga: Aljibe.

Demagistri, María Silvina, María Marta Richards, and Lorena Canet Juric. 2017. Incidencia Del Funcionamiento Ejecutivo En El Rendimiento En Comprensión Lectora En Adolescentes. Electronic Journal of Research in Education Psychology 12: 343-70. [CrossRef]

Diuk, Beatriz. 2003. El Proceso de Aprendizaje de La Lectura y La Escritura En Niños de Sectores Urbano-Marginados: Un Estudio Cognitivo. Ph.D. thesis, Universidad Nacional de La Plata, Buenos Aires, Argentina.

Diuk, Beatriz, María Adelaida Signorini, and Ana María Borzone. 2003. Las estrategias tempranas de lectura de palabras en niños de 1er. ciclo de E.G.B.: Un estudio comparativo entre niños procedentes de distintos sectores sociales. Psykhé 12: 51-62.

Diuk, Beatriz, Ana María Borzone, and Rubén Daniel Ledesma. 2010. Conocimiento de vocabulario, representaciones fonológicas y sensibilidad fonológica en niños pequeños de distinto sector social de procedencia. Summa Psicológica UST 7: 33-50. [CrossRef]

Duncan, Lynne G., Sarah P. McGeown, Yvonne M. Griffiths, Susan E. Stothard, and Anna Dobai. 2016. Adolescent Reading Skill and Engagement with Digital and Traditional Literacies as Predictors of Reading Comprehension. British Journal of Psychology 107: 209-38. [CrossRef] [PubMed]

Eason, Sarah H., Lindsay F. Goldberg, Katherine M. Young, Megan C. Geist, and Laurie E. Cutting. 2012. Reader-Text Interactions: How Differential Text and Question Types Influence Cognitive Skills Needed for Reading Comprehension. Journal of Educational Psychology 104: 515-28. [CrossRef] [PubMed]

Ehrlich, Marie-France, Beth Kurtz-Costes, and Catherine Loridant. 1993. Cognitive and Motivational Determinants of Reading Comprehension in Good and Poor Readers. Journal of Reading Behavior 25: 365-81. [CrossRef]

Ericsson, K. Anders, and Walter Kintsch. 1995. Long-Term Working Memory. Psychological Review 102: $211-45$. [CrossRef] [PubMed]

Feldman, Jacobo. 2009. Escalas Alfa-2 y Gamma. Buenos Aires: CEC Publicaciones.

Ferreres, Aldo, Valeria Abusamra, and Mario Squillace. 2010. Comprensión de Textos y Oportunidades Educativas. In Actas del Congreso Iberoamericano de Educación. Metas 2021. Edited by Organización de Estados Iberoamericanos. Buenos Aires: Universidad de Cádiz y Asociación Formación, pp. 1-11.

Ferreres, Aldo, Valeria Abusamra, Andrea Casajús, and Nancy China. 2011. Adaptación y estudio preliminar de un test breve para evaluar la eficacia lectora (TECLE). Neuropsicologia Latinoamericana 3: 1-7. [CrossRef]

Fletcher, Jack M., G. Reid Lyon, Lynn S. Fuchs, and Marcia A. Barnes. 2007. Reading disabilities: Comprehension. In Learning disabilities: From Identification to Intervention. Edited by Jack M. Fletcher, G. Reid Lyon, Lynn S. Fuchs and Marcia A. Barnes. New York: The Guilford Press, pp. 184-206.

Florit, Elena, Maja Roch, and M. Chiara Levorato. 2014. Listening Text Comprehension in Preschoolers: A Longitudinal Study on the Role of Semantic Components. Reading and Writing 27: 793-817. [CrossRef]

Fonseca, Liliana, María Pujals, Eleonora Lasala, Graciela Migliardo, Adriana Aldrey, Luciana Buonsanti, and Juan Pablo Barreyro. 2014. Desarrollo de Habilidades de Comprensión Lectora En Niños de Escuelas de Distintos Sectores Socioeconómicos. Neuropsicología Latinoamericana 6: 41-50.

Forster, Kenneth. 1976. Accessing the mental lexicon. In New Approaches to Language Mechanisms. Edited by Roger J. Wales and Edward Walker. Amsterdam: North Holland, pp. 257-87.

Fromkin, Victoria A. 1992. El léxico mental. In Panorama de la lingüística moderna de la Universidad de Cambridge. Tomo III: Aspectos Psicológicos y Biológicos. Edited by Frederick J. Newmayer. Madrid: Visor.

García, J. Ricardo, and Kate Cain. 2014. Decoding and Reading Comprehension: A Meta-Analysis to Identify Which Reader and Assessment Characteristics Influence the Strength of the Relationship in English. Review of Educational Research 84: 74-111. [CrossRef]

Gee, James Paul. 2005. La Ideología En Los Discursos: Lingüística Social y Alfabetizaciones. Madrid: Editorial Morata. Gough, Philip B., and William E. Tunmer. 1986. Decoding, Reading, and Reading Disability. Remedial and Special Education 7: 6-10. [CrossRef]

Graesser, Arthur C., Keith K. Millis, and Rolf A. Zwaan. 1997. Discourse Comprehension. Annual Review of Psychology 48: 163-89. [CrossRef] 
Hoover, Wesley A., and Philip B. Gough. 1990. The Simple View of Reading. Reading and Writing 2: 127-60. [CrossRef]

Jiménez, Juan E., and Claudia García de la Cadena. 2007. Learning Disabilities in Guatemala and Spain: A Cross-National Study of the Prevalence and Cognitive Processes Associated with Reading and Spelling Disabilities. Learning Disabilities Research \& Practice 22: 161-69.

Johnson-Laird, Philip Nicholas. 1983. Mental Models: Towards a Cognitive Science of Language, Inference, and Consciousness. Cambridge: Harvard University Press.

Joshi, R. Malatesha. 2005. Vocabulary: A critical component of comprehension. Reading \& Writing Quarterly 21: 209-19.

Kang, Eun Young, and Mikyung Shin. 2019. The Contributions of Reading Fluency and Decoding to Reading Comprehension for Struggling Readers in Fourth Grade. Reading E Writing Quarterly 35: 179-92.

Kendeou, Panayiota, Catherine Bohn-Gettler, Mary Jane White, and Paul van den Broek. 2008. Children's Inference Generation across Different Media. Journal of Research in Reading 31: 259-72. [CrossRef]

Kim, Young-Suk, Richard K. Wagner, and Elizabeth Foster. 2011. Relations among Oral Reading Fluency, Silent Reading Fluency, and Reading Comprehension: A Latent Variable Study of First-Grade Readers. Scientific Studies of Reading 15: 338-62. [CrossRef] [PubMed]

Kim, Young-Suk, Richard K. Wagner, and Danielle Lopez. 2012. Developmental Relations between Reading Fluency and Reading Comprehension: A Longitudinal Study from Grade 1 to Grade 2. Journal of Experimental Child Psychology 113: 93-111. [CrossRef]

Kintsch, Walter, and Katherine Rawson. 2007. Comprehension. In The Science of Reading: A Handbook. Edited by Margaret Snowling and Charles Hulme. Oxford: Blackwell Publishing, pp. 211-26.

Kress, Gunther. 2003. El Alfabetismo En La Era de Los Nuevos Medios de Comunicación. Málaga: Ediciones Aljibe.

Levelt, Willem JM, Ardi Roelofs, and Antje S. Meyer. 1999. A Theory of Lexical Access in Speech Production. Behavioral and Brain Sciences 22: 1-38. [CrossRef]

Lobrot, Michel. 1980. D-OR-LEC: Lire, Épreuves Pour Évaluer La Capacité de Lecture. Paris: ESF.

Lupo, Sarah M., Laura Tortorelli, Marcia Invernizzi, Ji Hoon Ryoo, and John Z. Strong. 2019. An Exploration of Text Difficulty and Knowledge Support on Adolescents' Comprehension. Reading Research Quarterly 54: 457-79. [CrossRef]

Marín, Javier, and Marisol Carrillo. 1999. Test Colectivo de Eficacia Lectora (TECLE). Unpublished manuscript. Murcia: Departamento de Psicología Básica y Metodología, Universidad de Murcia.

Megherbi, Hakima, Alix Seigneuric, and Marie-France Ehrlich. 2006. Reading Comprehension in French 1st and 2nd Grade Children: Contribution of Decoding and Language Comprehension. European Journal of Psychology of Education 21: 135-37. [CrossRef]

Nation, Kate, and Margaret Snowling. 1997. Assessing Reading Difficulties: The Validity and Utility of Current Measures of Reading Skill. British Journal of Educational Psychology 67: 359-70. [CrossRef]

Oakhill, Jane, Joanne Hartt, and Deborah Samols. 2005. Levels of Comprehension Monitoring and Working Memory in Good and Poor Comprehenders. Reading and Writing 18: 657-86. [CrossRef]

ONE. 2010. Recomendaciones Metodológicas para la Enseñanza. Lengua. Educación Primaria-ONE 2007. Pruebas de $3^{\circ}$ año y $6^{\circ}$ año Primaria. Dirección Nacional de Información y Evaluación de la Calidad Educativa. Ministerio de Educación de la Nación. Available online: http://repositorio.educacion.gov.ar: 8080/dspace/handle/123456789/109673 (accessed on 20 July 2020).

Ouellette, Gene P. 2006. What's Meaning Got to Do with It: The Role of Vocabulary in Word Reading and Reading Comprehension. Journal of Educational Psychology 98: 554-66. [CrossRef]

Papetti, Ombretta, Cesare Cornoldi, Antonietta Pettavino, Giuliana Mazzoni, and John Borkowski. 1992. Memory Judgments and Allocation of Study Times in Good and Poor Comprehenders. In Advances in Learning and Behavioral Disabilities. Edited by Thomas Scruggs and Margo Mastropieri. Greenwich: JAI, pp. 3-33.

Pazzaglia, Francesca, Cesare Cornoldi, and Patrizio Emanuele Tressoldi. 1993. Learning to Read: Evidence on the Distinction between Decoding and Comprehension Skills. European Journal of Psychology of Education 8: 247-58. [CrossRef]

Pazzaglia, Francesca, Paola Palladino, and Rossana De Beni. 2000. Presentazione Di Uno Strumento per La Valutazione Della Memoria Di Lavoro Verbale e Sua Relazione Con i Disturbi Della Comprensione. Psicologia Clinica Dello Sviluppo 4: 465-86. 
Perfetti, Charles A., and Thomas Hogaboam. 1975. Relationship between Single Word Decoding and Reading Comprehension Skill. Journal of Educational Psychology 67: 461-69. [CrossRef]

Perfetti, Charles A., Elyse Finger, and Thomas W. Hogaboam. 1978. Sources of Vocalization Latency Differences between Skilled and Less Skilled Young Readers. Journal of Educational Psychology 70: 730-39. [CrossRef]

Perfetti, Charles A., Nicole Landi, and Jane Oakhill. 2005. The Acquisition of Reading Comprehension Skill. In The Science of Reading: A Handbook. Edited by Margaret Snowling and Charles Ed Hulme. Oxford: Blackwell Publishing, pp. 227-47.

Piacente, Telma, Carmen L. Talou, and María Adelaida Rodrigo. 1990. Piden Pan ... y Algo Más. Un Estudio de Crecimiento y Desarrollo Infantil. España: Siglo XXI.

Piacente, Telma, Sandra Marder, Mariela Resches, and Ruben Ledesma. 2006. El Contexto Alfabetizador Hogareño En Familias de La Pobreza. Comparación de Sus Características Con Las de Familias No Pobres. Revista Iberoamericana de Diagnóstico y Evaluación Psicológica 1: 61-88.

Pimperton, Hannah, and Kate Nation. 2010. Suppressing Irrelevant Information from Working Memory: Evidence for Domain-Specific Deficits in Poor Comprehenders. Journal of Memory and Language 62: 380-91. [CrossRef]

Querejeta, Maira Gisela, Telma Piacente, Sandra Esther Marder, and Mariela Resches. 2005. Características Del Contexto Alfabetizador En Familias de Diferente Nivel Socioeconómico. In Estudios sobre la adquisición de las lenguas del Estado. Edited by María Ángeles Mayor, Begoña Zubiauz and Emiliano Diez-Villoria. Salamanca: Ediciones de la Universidad de Salamanca, pp. 803-18.

Rosemberg, Celia Renata, and Alejandra Stein. 2016. Análisis longitudinal del impacto de un programa de alfabetización temprana. Revista Latinoamericana de Ciencias Sociales, Niñez y Juventud 14: 1087-102.

Rosemberg, Celia Renata, Alejandra Stein, and Alejandra Menti. 2011. Orientación educativa sobre el vocabulario y el acceso a la alfabetización. Evaluación de impacto de un programa de intervención en las familias y en la escuela. Revista Internacional e Interdisciplinaria de Orientación Vocacional Ocupacional 11: 41-62.

Sesma, Heather Whitney, E. Mark Mahone, Terry Levine, Sarah H. Eason, and Laurie E. Cutting. 2009. The Contribution of Executive Skills to Reading Comprehension. Child Neuropsychology 15: 232-46. [CrossRef]

Signorini, María Adelaida, and Telma Piacente. 2003. Diferencias Individuales En Lectura En Niños Pequeños: Vinculando El Desarrollo Normal y Las Dificultades. Revista IRICE 17: 49-78.

Snow, Catherine. 2002. Reading for Understanding: Toward an RED Program in Reading Comprehension. Santa Monica: Rand Corporation.

Spencer, Mercedes, Richard K. Wagner, and Yaacov Petscher. 2019. The Reading Comprehension and Vocabulary Knowledge of Children with Poor Reading Comprehension despite Adequate Decoding: Evidence from a Regression-Based Matching Approach. Journal of Educational Psychology 111: 1-14. [CrossRef]

Stanovich, Keith E. 1993. Does Reading Make You Smarter? Literacy and the Development of Verbal Intelligence. In Advances in Child Development and Behavior. Edited by Hayne Reese. San Diego: Academic Press, vol. 24, pp. 133-80.

Swanson, H. Lee, and Rollanda O'Connor. 2009. The Role of Working Memory and Fluency Practice on the Reading Comprehension of Students Who Are Dysfluent Readers. Journal of Learning Disabilities 42: 548-75. [CrossRef] [PubMed]

Tilstra, Janet, Kristen McMaster, Paul Van den Broek, Panayiota Kendeou, and David Rapp. 2009. Simple but Complex: Components of the Simple View of Reading across Grade Levels. Journal of Research in Reading 32: 383-401. [CrossRef]

Tsimpli, Ianthi Maria, Margreet Vogelzang, Anusha Balasubramanian, Theodoros Marinis, Suvarna Alladi, Abhigna Reddy, and Minati Panda. 2020. Linguistic Diversity, Multilingualism, and Cognitive Skills: A Study of Disadvantaged Children in India. Languages 5: 10. [CrossRef]

Van Dijk, Teun Adrianus, and Walter Kintsch. 1983. Strategies of Discourse Comprehension. New York: Academic Press.

Vellutino, Frank R., William E. Tunmer, James J. Jaccard, and RuSan Chen. 2007. Components of Reading Ability: Multivariate Evidence for a Convergent Skills Model of Reading Development. Scientific Studies of Reading 11: 3-32. [CrossRef]

Verhoeven, Ludo, and Jan Van Leeuwe. 2008. Prediction of the Development of Reading Comprehension: A Longitudinal Study. Applied Cognitive Psychology: The Official Journal of the Society for Applied Research in Memory and Cognition 22: 407-23. [CrossRef] 
Wechsler, David. 2005. Escala de Inteligencia Wechsler para Niños-IV. Madrid: TEA.

Yamashita, Toshie, Keizo Yamashita, and Ryotaro Kamimura. 2007. A stepwise AIC method for variable selection in linear regression. Communications in Statistics-Theory and Methods 36: 2395-403. [CrossRef]

Zwaan, Rolf A., and Gabriel A. Radvansky. 1998. Situation Models in Language Comprehension and Memory. Psychological Bulletin 123: 162-85. [CrossRef] [PubMed]

Zwaan, Rolf A., Joseph P. Magliano, and Arthur C. Graesser. 1995a. Dimensions of Situation Model Construction in Narrative Comprehension. Journal of Experimental Psychology: Learning, Memory, and Cognition 21: 386-97. [CrossRef]

Zwaan, Rolf A., Mark C. Langston, and Arthur C. Graesser. 1995b. The construction of situation models in narrative comprehension: An event-indexing model. Psychological Science 6: 292-97. [CrossRef]

Zwaan, Rolf A., Gabriel A. Radvansky, Amy E. Hilliard, and Jacqueline M. Curiel. 1998. Constructing Multidimensional Situation Models during Reading. Scientific Studies of Reading 2: 199-220. [CrossRef]

(C) 2020 by the authors. Licensee MDPI, Basel, Switzerland. This article is an open access article distributed under the terms and conditions of the Creative Commons Attribution (CC BY) license (http://creativecommons.org/licenses/by/4.0/). 